\title{
As Diretivas Antecipadas de Vontade no contexto da terminalidade da vida: discussão acerca da necessidade de uma lei específica regulamentadora
}

Anticipated Directives of Will in the context of terminality of life: discussion about the need for a specific regulatory law

Directivas Anticipadas de Voluntad en el contexto de la terminalidad de la vida: discusión sobre la necesidad de una ley reguladora específica

Kethlyn de França dos Santos ORCID: https://orcid.org/ 0000-0002-9580-8891 Instituto Federal do Paraná, Brasil E-mail: kethlynfs@gmail.com

Francieli Maria de Lima

ORCID: https://orcid.org/0000-0003-4221-3103 Instituto Federal do Paraná, Brasil E-mail: francieli.lima@ifpr.edu.br

\begin{abstract}
Resumo
Objetiva-se com este manuscrito analisar aspectos do ordenamento jurídico brasileiro relacionados às diretivas antecipadas de vontade e discutir acerca da necessidade de uma lei específica regulamentadora. O estudo foi realizado através do método dedutivo, ancorado na pesquisa bibliográfica e na investigação dos princípios fundamentais e constitucionais, bem como de resoluções do Conselho Federal de Medicina. Nos resultados e discussão, são apresentados três subtítulos explorando a temática. No primeiro subtítulo, são delimitados os princípios constitucionais se encontram associados com as diretivas, destacando-se a relevância dos princípios na implementação das mesmas. No segundo, ocorre um aprofundamento da temática das diretivas, a partir do esclarecimento de conceitos e termos correlatos. No terceiro subtítulo, explora-se o ordenamento jurídico nacional em torno das diretivas antecipadas e uma discussão é tecida acerca da necessidade de uma lei brasileira que trate especificamente das mesmas, sendo descritos importantes instrumentos jurídicos compatíveis com as diretivas. Avaliou-se que as diretivas encontram amparo legal na nossa carta magna e em outros dispositivos do ordenamento jurídico brasileiro, no entanto, a ausência de uma lei disciplinadora limita seu uso. Assim, evidencia-se que a discussão nesse sentido precisa alavancar e que a aprovação de uma lei que disciplinasse as diretivas antecipadas de vontade seria um ganho para a sociedade.
\end{abstract}

Palavras-chave: Diretivas antecipadas de vontade; Dignidade humana; Autonomia do paciente; Ordenamento jurídico.

\begin{abstract}
The objective of this manuscript is to analyze aspects of the Brazilian legal system related to advance directives of will and discuss the need for a specific regulatory law. This is a study carried out using the deductive method, based on bibliographical research and on the study of fundamental and constitutional principles, as well as on the resolutions of the Federal Council of Medicine. In the results and discussion, three subtitles are presented exploring the theme. In the first subtitle, the constitutional principles that are related to the directives are delimited, highlighting the importance of the principles in their implementation. In the second, there is a deepening of the theme of the directives, based on the clarification of related concepts and terms. The third subtitle explores the Brazilian legal system around the advance directives of will and a discussion is woven about the need for a specific regulatory law, describing important legal instruments compatible with the directives. It was evaluated that the directives find legal support in the Federal Constitution and in other provisions of the Brazilian legal system, however, the absence of a specific law limits their use. Thus, it is concluded that the discussion in this sense needs to advance and that the approval of a law that would discipline the advance directives of will would be a gain for society.
\end{abstract}

Keywords: Anticipated directives of will; Human dignity; Patient autonomy; Legal order.

\section{Resumen}

El propósito de este manuscrito es analizar aspectos del sistema legal brasileño relacionados con las directivas anticipadas de la voluntad y discutir la necesidad de una ley reguladora específica. Se trata de un estudio realizado por el método deductivo, basado en la investigación bibliográfica y en el estudio de los principios fundamentales y 
constitucionales, así como en las resoluciones del Consejo Federal de Medicina. En los resultados y la discusión, se presentan tres subtítulos explorando el tema. En el primer subtítulo se delimitan los principios constitucionales que se relacionan con las directivas, destacando la importancia de los principios en su implementación. En el segundo, se profundiza en el tema de las directivas, a partir de la aclaración de conceptos y términos relacionados. El tercer subtítulo explora el sistema legal brasileño en torno a las directivas anticipadas del testamento y se teje una discusión sobre la necesidad de una ley reguladora específica, describiendo importantes instrumentos legales compatibles con las directivas. Se evaluó que las directivas encuentran sustento legal en la Constitución Federal y en otras disposiciones del ordenamiento jurídico brasileño, sin embargo, la ausencia de una ley específica limita su uso. Así, se concluye que la discusión en este sentido necesita avanzar y que la aprobación de una ley que disciplinaría las directivas anticipadas de voluntad sería una ganancia para la sociedad.

Palabras clave: Directivas de testamento anticipado; Dignidad humana; Autonomía del paciente; Ordenamiento jurídico.

\section{Introdução}

A evolução da Medicina e de áreas afins tem possibilitado a criação de inúmeros métodos tecnológicos de diagnóstico e tratamento, que postergam à vida e trazem novos dilemas éticos à sociedade contemporânea. De um lado, a medicina e a ciência lutando contra a morte, e de outro, o paciente e a família, muitas vezes, em intenso sofrimento, exauridos mediante tantos procedimentos invasivos, que por vezes, não garantem a cura e nem um melhor prognóstico, apenas prolongam a vida.

Ante a este cenário, observam-se discussões acerca da real necessidade destes procedimentos, que culminam em questionamentos autênticos e que se fazem valer de princípios fundamentais ditados pela bioética ou até mesmo por normas ou leis anteriormente postuladas, visando o bem-estar maior e a morte digna da pessoa enferma. No contexto nacional, observa-se uma discussão ainda inesgotada no que se refere às diretivas antecipadas de vontade (DAV's), que se justificam pela importância da expressão do paciente acerca de sua vontade no que se refere à terapêutica a ser empregada.

Esta temática envolve várias disciplinas, dentre as quais podem ser citadas a Medicina, a Bioética e o Direito, trazendo à tona a complexidade de postular ações no âmbito jurídico, que amparem a sociedade civil neste sentido. Adicionalmente, não há uma lei específica aprovada que regulamente sua utilização, ao mesmo tempo, que cresce o número de pessoas na terminalidade de vida, que deixam manifestações de suas vontades para seguimento pelos serviços de saúde e profissionais de saúde.

Portanto, ao se deparar com estas questões, gestores, profissionais da saúde, pacientes e familiares, bem como agentes da lei e profissionais jurídicos, enfrentam grandes desafios, se debatendo em empasses, pois ainda falta clareza de evidências que justifiquem tomadas de decisões. Assim, visualiza-se cotidianamente, cada vez mais a necessidade de se discutir e refletir acerca da utilização das DAV’s e a eficácia das normas e leis já existentes para defender sua aplicação.

Desse modo, percebe-se a relevância do desenvolvimento de trabalhos acadêmicos que tratem deste assunto. Os principais questionamentos disparadores da presente pesquisa são: o ordenamento jurídico brasileiro consegue garantir a efetivação da aplicação das DAV's? Haveria necessidade de uma lei especifica para este fim? Logo, o objetivo deste trabalho é analisar aspectos do ordenamento jurídico brasileiro relacionados às diretivas antecipadas de vontade e discutir acerca da necessidade de uma lei específica regulamentadora.

\section{Metodologia}

No presente trabalho, utiliza-se da pesquisa bibliográfica e do estudo dos princípios fundamentais e constitucionais, assim como das resoluções do Conselho Federal de Medicina, para alcançar objetivo proposto, a partir do método de abordagem dedutivo. Nesse método se utiliza de argumentos, observações, casos gerais para obter determinadas conclusões particulares. Trata-se, a dedução, de um caminho das consequências, uma vez que é possibilitado uma cadeia de raciocínio em conexão descendente. Assim, parte-se do geral e chega-se ao particular, trazendo uma conclusão. A partir de sua aplicação, 
verifica-se que ao partir de teorias e leis gerais, encontra-se a determinação ou previsão de fenômenos específicos. (Andrade, 2001).

Para responder às perguntas e ao objetivo proposto, a análise é traçada em três subtítulos específicos. No primeiro, são abordados os princípios constitucionais utilizados no caso de terminalidade de vida, em que os profissionais se ancoram para a realização das DAV's. Discute-se a autonomia privada, a dignidade da pessoa humana, bem como o direito à vida e autonomia durante o processo da morte digna.

No segundo, as DAV’s são exploradas com maior profundidade. Os conceitos e os aspectos históricos são destacados, além de suas modalidades, que são o testamento vital e o mandado duradouro. Retrata-se ainda, conceituações correlatas às DAV’s, sendo estas a eutanásia, distanásia e ortotanásia.

Por fim, no terceiro subtítulo, o ordenamento jurídico brasileiro é identificado e analisado, sendo destacadas as resoluções do Conselho Federal de Medicina, os projetos de lei, e ainda, trechos da Constituição da República Federativa do Brasil, Código Civil e Código Penal que tratam de algum modo, questões relacionadas às DAV’s, além de ser realizada uma análise específica dos autores acerca da necessidade de uma lei específica regulamentora que trate do assunto em questão.

\section{Resultados e Discussão}

\subsection{Princípios constitucionais aplicáveis na terminalidade da vida}

Alguns arcabouços importantes estão dispostos na Constituição da República Federativa do Brasil que permitem a ponderação de aspectos importantes na análise de situações, e que respaldam ações e tomadas de decisões no âmbito jurídico. Desse modo, remonta-se a relevância dos princípios bem como seu significado no ordenamento jurídico.

Destaca-se que os princípios se caracterizam como elementos essenciais utilizados para embasar os direitos fundamentais dos indivíduos. A partir de sua aplicação, demarca-se um ponto fixo de partida para o desenvolvimento de respostas para questionamento acerca dos direitos das pessoas, sendo considerados pilares no desenvolvimento de teorias diversas (Fuerst \& Paula, 2021). Alexy (2015) corrobora ao compreender os princípios também como fundamentos norteadores na elaboração de teses jurídicas, divergindo seu sistema de aplicação em conformidade com o caso concreto.

Os princípios dão origem aos institutos, orientam e conduzem a criação e interpretação das demais regras. Os princípios são uma espécie de mandamentos norteadores de decisões, sendo que as premissas de aplicação no âmbito jurídico e real são diferenciadas a partir da adequação do fato à norma. Ressalta-se ainda que quando um princípio incide de forma mais ampla que outro, pode haver colisões, entretanto, eles não se excluem no caso concreto. Quando isso ocorre, não se invalida um princípio em relação a outro, acontece que um terá precedência no tocante ao outro em determinadas situações (Alexy, 2015).

Desse modo, podemos referir a importância dos princípios devido a esse caráter regulador que estes apresentam. Assim, eles são importantes para as mais diversas discussões éticas e jurídicas, trazendo à tona sempre os direitos dos seres humanos diante determinada situação, o que é mais importante e o que não é, em cada caso. Justamente por isso, não há nada muito fixo de como se proceder em determinada situação, o que acaba gerando empasses e fomentando ainda mais discussões.

Para Fuerst \& Paula (2021), no momento de aplicação dos princípios, não há uma limitação da garantia de uma única e exclusiva maneira de interpretação, devido ao fato de ser evidenciado a característica dinâmica de sua aplicabilidade e generalidade funcional, em comparação com outras normas. No que se refere ao seguimento da Constituição da República Federativa do Brasil, os princípios tratam-se de pilares fundamentais para a construção do ordenamento jurídico. De forma geral, apresentam linhas mestras e diretrizes de criações legislativas, sendo capazes de delinear toda interpretação, estabelecendo condutas obrigatórias em situações específicas e permitindo o preenchimento de lacunas que surgem em decorrência de falha deixada por uma norma já estabelecida ou devido à ausência de alguma legislação (Fuerst \& Paula, 2021). 
Assim, visualiza-se que os princípios constitucionais são de extrema valia para o ordenamento jurídico brasileiro, constituindo sua primazia, sendo capazes de ancorar decisões que envolvem, por exemplo, as DAVS's, sendo um norte para decisões que envolvem esta pauta. Dessa forma, faz-se necessário compreender de forma mais aprofundada os princípios que são aplicáveis em casos que envolvem estas diretrizes. Trataremos, portanto, da relação de importantes princípios constitucionais e sua relação com as DAV’s, a saber: autonomia, dignidade humana e direito à vida.

Ao tratarmos da autonomia, cabe destacar que esse conceito vem se transformando ao longo dos anos, juntamente com a história da humanidade. Nem sempre esteve claro seu significado e seu uso ocorreu de distintas formas, a partir de perspectivas diferentes, o que será elucidado a seguir. Distingue-se também, autonomia privada de autonomia de vontade.

Para Naves (2014) a terminologia autonomia privada apareceu para substituir a autonomia de vontade, sendo que, na sociedade de massa, a partir das demandas crescentes e uma grande necessidade de legitimar os direitos das pessoas, não só aqueles individuais como também de todo o coletivo, não bastando o atendimento às vontades das partes, mas, sim, garantir uma forma de concretizar esta vontade. Assim, afirma-se que a autonomia privada surge para substituir a carga individualista e liberal da autonomia de vontade.

A autonomia privada encontra barreiras na ordem pública e em normas legais, tendo em vista que em grande número de casos, na ocorrência de omissão das partes em relação a algum aspecto de âmbito jurídico, o direito exercerá a função de suprir a declaração das partes (Borges, 2005). Não obstante, visualiza-se que os sujeitos sempre tiveram a oportunidade de exercitar sua autonomia de vontade, entretanto, com o avanço histórico, incumbiu a legislação dar forma ao exercício dessa vontade, impondo limites às vontades. Isto posto, verifica-se que a autonomia privada consiste, no poder conferido aos particulares pelo ordenamento jurídico de criação das normas jurídicas dentro dos limites regulamentados na legislação (Pargendler, 2004).

Penalva (2009) traz que a autonomia privada da pessoa deve ser compreendida como a possibilidade de poder buscar seus interesses individuais sem que tenha implicações conflituosas com a autonomia pública, preservando assim a existência conjunta de todos os projetos de vida dos sujeitos. Distingue-se que a autonomia privada se constitui no gênero, enquanto que a autonomia da vontade pode ser considerada a espécie, sendo que esta última estaria vinculada à vontade interna (psíquica) e à liberdade de atuação de cada ser, possibilitando escolha do tipo de obrigação a que se pretende aderir, enquanto que a primeira, teria relação direta com a liberdade de contratação, isto é, com a formulação de normas para si. Interessa dispor que independentemente das divergências quanto ao significado semântico de cada uma delas, ambas se caracterizam como liberdades fundamentais que devem estar à disposição de cada sujeito (Reckziegel \& Fabro, 2015).

Naves e Rezende (2007) descrevem que o princípio da autonomia privada está vinculado com a ideia de liberdade e também com a autodeterminação individual. Assim, ao pensar na terminalidade de vida e nas pessoas que se encontram nesta situação, este princípio caminha juntamente com o princípio da bioética do respeito à pessoa, sendo que este trata da capacidade da pessoa doente de tomar decisões sobre o tratamento ou experimento aos quais será submetido. Dessa maneira, o princípio da autonomia impõe que os profissionais de saúde respeitem a vontade do paciente ou de seu representante, bem como os valores morais e crenças que eles carregam. Através ainda deste, deve ser reconhecido o domínio do enfermo sobre a sua própria vida e respeitar a sua intimidade, limitando assim, a intromissão de outros indivíduos no mundo da pessoa assistida.

A autonomia da vontade não se constitui nosso objeto principal de estudo, pois referimos aqui a uma autonomia que sofre intervenção do Estado e apesar de defender um interesse individual, não há um prejuízo da vontade de terceiros. Assim, há uma preocupação com o coletivo, portanto, referimo-nos a importância da autonomia privada como um princípio para orientar as legislações existentes e as ações das pessoas. 
Em adição, evidencia-se que a autonomia privada, conformada pelo ordenamento jurídico, diz respeito a possibilidade de o sujeito determinar o conteúdo, a forma e/ou os efeitos do negócio jurídico. Considerando isso, em uma situação concreta, o indivíduo pode determinar somente conteúdo e efeitos, sendo a lei responsável pela determinação da forma (Naves, 2014). Em geral, os médicos precisam tomar decisões pelos pacientes, em relação ao que é melhor para ele na impossibilidade de manifestação de seus desejos. Aponta-se que a existência de divergências entre profissionais de saúde e os enfermos podem resultar em um prolongamento da vida a qualquer custo, somado a uma confusão moral entre os trabalhadores da saúde, a família e o paciente, sem ganhos para este último.

Nesse sentido, as DAV's são entendidas como uma eficiente maneira de aumentar a autonomia do paciente. Acrescenta-se que no desejo do enfermo em "controlar a sua morte", é necessário avaliar se isso está acompanhado de uma compreensão adequada do processo da morte, assim como se o mesmo busca o controle de sua patologia ou compaixão, uma vez que esta barganha não lhe nega a prática da autonomia, ao contrário disso, possibilita uma visão mais clara, constituindo uma ação autônoma e autêntica. Em consonância com este princípio, a capacidade de decisão dos sujeitos deve ser respeitada, sendo que a obtenção do seu consentimento para a realização de qualquer procedimento médico é a forma maior de demonstrar respeito à autonomia do paciente (Barbosa, 2019).

Posto isto, vale ressaltar que as DAV's se caracterizam como um documento que vai dispor acerca de como o paciente quer seu tratamento, portanto, seu seguimento visa preservar a autonomia do mesmo. Sua declaração livre e sem equívocos, mediante a clarificação das informações de modo objetivo, sem interferência externa, corresponde ao exercício de seu direito, sua própria autodeterminação, acerca de quais tratamentos ou métodos diagnósticos quer ou não se sujeitar.

Em resumo, a base para suspender ou manter esforço terapêutico nos serviços de assistência à saúde é o respeito à autonomia e à autodeterminação dos pacientes. É um dever dos profissionais de saúde este respeito, inclusive nas situações em que se pede a alta "a pedido", em que é proporcionado a ocorrência da morte no local de preferência do enfermo, bem como no tempo e companhia desejados. Isso significa, portanto, que omitir tratamentos a partir do pedido do paciente ou por sua recusa não caracteriza um crime ou muito menos pode ser chamado de eutanásia passiva ou ainda homicídio a pedido. É justamente o contrário, a falta de respeito pelo direito de morrer do usuário dos serviços de saúde, o desrespeito à sua autodeterminação, que pode ocasionar um ato criminoso, caracterizando um constrangimento ilegal, abuso de poder e até mesmo uma lesão corporal (Barbosa, 2019).

Desse modo, pondera-se a importância deste princípio - autonomia privada -, na avaliação de casos concretos envolvendo as DAV's, que deve ser respeitado juntamente com demais disposições legais. A autonomia privada está intrinsecamente ligada aos outros princípios, a serem explorados a seguir. Esse princípio também carrega interrelação com o princípio da dignidade humana, discutido a seguir.

Remonta-se a dignidade humana como um dos princípios basilares, ao qual os seres humanos usufruem, sendo essencial para a manutenção de um estado de bem-estar e para a comunhão de todos os que habitam na sociedade. Ele ampara e embasa diversos casos concretos, que recorrem, em prol da dignidade daquele a quem este direito é renegado. Para dar continuidade a esse raciocínio traçado, precisamos compreender fatidicamente a origem e o conceito por trás deste princípio fundamental.

A dignidade humana nasceu há séculos com a filosofia, a partir de pensadores inovadores da época como Cícero, Pico della Mirandola e Immanuel Kant, que dispuseram ideias como o antropocentrismo, o valor inerente a cada ser e a capacidade de cada sujeito ter acesso à razão, fazer escolhas morais e determinar seu próprio caminho. No século XX, especialmente no período pós Segunda Guerra Mundial, incorporou-se a ideia de dignidade humana ao discurso político das grandes nações que venceram o conflito, se tornando uma espécie de meta política almejada por instituições nacionais e internacionais (Barroso, 2014). 
Na Constituição da República Federativa do Brasil de 1988, a dignidade da pessoa humana, um dos pilares do Estado Democrático de Direito, encontra-se expressa no artigo $1^{\circ}$, inciso III: “Art. $1^{\circ}$ A República Federativa do Brasil, formada pela união indissolúvel dos Estados e Municípios e do Distrito Federal, constitui-se em Estado Democrático de Direito e tem como fundamentos: a soberania; a cidadania; a dignidade da pessoa humana; os valores sociais do trabalho e da livre iniciativa [...] (Brasil,1988).

Dispõe-se acerca de uma dimensão dupla da dignidade. Em primazia, a proteção e promoção da dignidade humana eram consideradas competências exclusivas dos poderes Executivo e Legislativo do Estado, ou seja, poder político. No entanto, ocorreu, sem que demorasse muito, que essas metas políticas e valores morais arraigados na dignidade se fundamentassem do direito, migrando-se para este campo do saber. Destaca-se a característica desse conceito ser multifacetado, demarcando a presença em âmbitos religiosos, filosóficos, políticos e jurídicos. Existe um consenso de que o mesmo apresenta valoração fundamental subjacente às democracias constitucionais de modo geral, mesmo quando não está descrito expressamente em suas constituições (Barroso, 2014).

Para Sarlet (1998) a dignidade da pessoa humana trata-se de uma qualidade intrínseca, que não se separa de todo e qualquer indivíduo, sendo que está característica é a que define como tal. Diz respeito à uma concepção de que devido sua condição de ser humano - condição humana - e independentemente de qualquer outra especificidade, todo indivíduo é titular digno - de direitos, os quais devem ser respeitados por todos os outros humanos e pelo Estado. Em acordo, Barbosa (2019) afirma que a dignidade se traduz na consciência do indivíduo acerca de seu próprio valor, inspirando respeito, honradez, independentemente de qualquer disposição estatal para que haja legitimação.

Kant (2009) através de sua obra "A fundamentação da metafísica dos costumes" trata acerca da dignidade, utilizando dois adjetivos: incondicional e incomparável. O primeiro está ligado a sua capacidade de ser independente de fatos contingentes ou de uma situação específica para ser estabelecida. O autor afirma que: "aquilo (...) que constitui a condição só graças à qual qualquer coisa pode ser um fim em si mesma, não tem somente um valor relativo, isto é, um preço, mas um valor intrínseco, isto é, dignidade". Kant, 2009). Complementa ainda, se existe o Imperativo Categórico, deve ter "alguma coisa cuja existência em si mesma tenha um valor absoluto e que, como fim em si mesmo, possa ser a base de leis determinadas" (Kant, 2009).

Assim, aponta-se que a valoração da dignidade está somente em si mesmo e nunca em algo relacionado aos efeitos dela derivados ou ainda na vantagem e utilidade proporcionada. Independe ainda de um preço de mercado e de um preço afetivo, por si só ela existe e assim todo indivíduo deve usufruir da dignidade. Se nasceu como ser humano, não pode ser estabelecida nenhuma condição para este ter dignidade, este tem direito a dignidade simplesmente por isso.

A característica "incomparável" distingue a dignidade algo que tem seu valor "acima de todo o preço" (KANT, 2009, p. 434-435), sem nenhuma equivalência. Kant (2009) continua: "quando uma coisa tem um preço, pode-se pôr em vez dela qualquer outra como equivalente; mas quando uma coisa está acima de todo o preço, e, portanto, não permite equivalente, então tem ela dignidade".

Assim, não há um valor de mercado ou afetivo que se compare a dignidade, sendo que está última sempre se sobressai, sendo que não pode ser destruída ou prejudicada em detrimento de um fim que possui valor relativo, muito menos pode ser objeto de troca por outro que possui um preço de mercado estipulado. Não há como comparar a dignidade, por ser algo considerado como bem maior à existência de qualquer outro.

Ainda, ancorando-se em Kant, a dignidade humana se baseia no caráter racional do indivíduo, que a torna digna por natureza, simplesmente pelo ser humano ter nascido com vida. Nesse contexto, não é possível visualizá-la como uma concessão do Estado, mas sim como uma característica que os sujeitos possuem, sem estabelecimento de qualquer condição 
prévia para usufrui-la. Assim, a dignidade humana é uma qualidade pertencente ao indivíduo e não uma permissão do Estado, e desse modo, pouco interessa se o ordenamento jurídico reconhece a esta ou não (Barbosa, 2019).

O Estado não regulamenta a dignidade, isto é, não diz quem tem ou não direito a dignidade, visto outrora que todos devem vivenciar a dignidade humana, apenas a reconhece como um princípio, o qual é tão importante quanto o direito à vida. Cabe a ele resguardar e dispor acerca de meios de garantir que todos os cidadãos vivam com dignidade, pois nem todos tem condições para isso.

Consensualmente, a dignidade da pessoa humana é o pressuposto para todos os demais direitos fundamentais, incluindo o direito à vida, tratando-se de um fundamento para a valorização da vida, que precede a compreensão de um direito à uma vida digna, entretanto não de maneira absoluta, uma vez que se houvesse obrigação, se tornaria um dever à vida (Cunha, 2019). Acrescenta-se que por ser um valor fundamental e ao mesmo tempo um princípio constitucional, a dignidade humana exerce função tanto de justificação moral quanto de fundamento jurídico-normativo dos direitos fundamentais (Barroso, 2014).

Contudo, é relevante observar que anteriormente a constituição vigente, o Brasil vivenciava um período em que o ser humano era desvalorizado pelo Estado, destacando-se que milhares de pessoas passaram por maus tratos em decorrência simplesmente de não convergirem com a ideologia e os propósitos predominantes. Logo, ao explicitar a dignidade da pessoa humana como fundamento essencial, o Estado passou a reconhecer a primazia do indivíduo como titular de direitos e deveres, sendo, portanto, o centro e o fim de todo o ordenamento jurídico (Barbosa, 2019).

Desse modo, o zelo pela dignidade humana é um bem supremo, soberano e essencial representando na Constituição Federal de 1988, considerado uma prerrogativa básica, de valor máximo e absoluto. Entretanto, não há um conceito fixo de dignidade da pessoa humana na Carta Magna, ou ainda na Declaração Universal dos Direitos Humanos, e em nenhum outro documento internacional, sendo assim, esta responsabilidade fica a encargo de juristas, doutrinadores e tribunais. No entanto, crê-se que há um ponto em comum, que seria a proteção dos direitos básicos dos sujeitos, tendo a liberdade como um dos seus pilares. De fato, é sua aplicação que permite às pessoas a prática de seus direitos essenciais, devido simplesmente ao fato de nacer com vida (Barbosa, 2019,).

Dessa maneira, cabe ressaltar que o princípio da dignidade da pessoa humana apresenta muitas funções no ordenamento jurídico brasileiro. Este princípio vincula o Estado e seus cidadãos, envolvendo prestações positivas e negativas. Além disso, de acordo com Sarmento (2016): "é fundamento moral do Estado e do Direito, diretriz hermenêutica de todo o sistema jurídico, norte para a ponderação de interesses, parâmetro de validade dos atos estatais e privados, limite para o exercício de direitos, critério para a identificação de direitos fundamentais e fonte de direitos não enumerados na Constituição."

Uma questão que gera contraversão e é considerada delicada trata-se da relação entre o princípio da dignidade humana e o da autonomia. Isto porque uma pode implicar na outra, trazendo um desafio considerável. Existem aqueles que entendem que a dignidade significa respeito a autonomia e outros que afirmam que a autonomia deve ser limitada quando se trata de uma questão de indignidade.

Assim, de um lado, há um sólido consenso no sentido de que tratar os indivíduos como dignos implica no reconhecimento de seu direito de realizar escolhas pessoais e seguir, desde que não atinja direitos alheios. Em contrapartida, há uma sustentação de que é necessário limitar a autonomia das pessoas, para impedir que as mesmas se submetam a situações indignas, mesmo que isso se deva à sua própria vontade (Sarmento, 2016).

Assim, devemos novamente ressaltar que a interpretação de cada caso é importante para delimitar atos jurídicos. Ademais, cabe destacar que a dignidade da vida humana também deve ser pensada para além das condições de vida de um sujeito. Deve ser lembrado, portanto, que quando falamos em dignidade, é necessário pensar na dignidade da morte, devendo haver um diálogo que inclua isso e seja capaz de oportunizar o respeito da sociedade. 
Com relação a isso, Dayrell (2010) descreve que se percebe uma evidente violação à dignidade do indivíduo a partir do momento em que se inicia um tratamento sabidamente ineficaz frente a uma morte que não se pode evitar e a irreversibilidade deste processo. Possivelmente, ocorrerá uma postergação da morte, mediante sofrimento e indignidade, mas não será postergada a vida. Geralmente, a vontade do paciente é ignorada nestes casos. Além disso, ressalta-se que o prolongamento artificial de seu processo de morrer, resulta em uma alienação em relação à sociedade e à sua própria vida, uma vez que o paciente não poderá exercer suas relações sociais com dignidade, e nem poderá "viver" de modo considerado normal (Dayrell, 2010).

Ao findar este subtítulo, admite-se, portanto, assim como os autores apresentados neste, a essencialidade do princípio da dignidade humana. Ele está imposto em todos os demais princípios e serve como argumento nos mais diversos casos, inclusive na terminalidade de vida. Quando da ocorrência desta, as justificativas se pautam no direito à uma morte digna, e deve-se lembrar que esta dignidade é inerente ao ser humano.

Em alguns contextos, há divergências quanto ao que seria digno e indigno, principalmente quando o uso desse princípio é questionado juntamente com a autonomia do paciente. Vale destacar assim que a conduta vai variar de caso a caso. No ordenamento jurídico brasileiro inexiste uma lei específica que regulamente as DAV’s, assim, a dignidade humana é muito utilizada para alicerçar este fim.

Ao findar a discussão acerca dos conceitos de autonomia e dignidade da pessoa humana, nos resta discutir o princípio do direito à vida e pensar a respeito da autonomia do indivíduo no processo de morrer dignamente. A vida é um bem supremo, não há como negar. Assim, este direito é inerente, pois sem vida, não haveria como existir outro direito. Dessa forma, todo e qualquer outro direito perpassa pela necessidade de o Estado resguardar esse direito primário. Direito à vida se relaciona diretamente ao direito à dignidade da pessoa humana, visto que não é somente necessário manter as funções vitais ativas de um indivíduo, este requer minimamente condições básicas de vida.

O direito à vida é considerado o principal direito assegurado pela nossa Constituição Federal em seu artigo $5^{\circ}$, sendo inviolável (Brasil, 1988). Os outros direitos derivariam destes, como a liberdade, igualdade, segurança e o direito à propriedade, uma vez que nenhum outro direito pode ser usufruído sem a vida (Carvalho, 2012). Nas palavras de Tavares (2012), se consagra como o mais básico de todos os direitos, uma vez que implica no seu surgimento como verdadeiro prérequisito da existência dos demais direitos consagrados constitucionalmente. Ainda para o autor, o conteúdo do direito à vida apresenta duas vertentes: em primeiro lugar, no direito de garantir e manter sua existência, e, em segundo lugar, o direito a um nível de vida adequado. Desse modo, inicialmente, deve ser assegurado aos indivíduos o simples direito se manter vivo, isto é, que ele exista até a interrupção da vida por formas naturais. A maneira de isso ocorrer tem a ver com a manutenção da segurança pública, com a proibição da justiça privada e com o respeito à vida de seus cidadãos por parte do Estado e dos outros civis.

Assim, entende-se que o direito à vida no Brasil é inerente à condição humana, sendo um direito de personalidade, um bem que transcende sua grandeza e pertence a qualquer indivíduo da espécie humana, independentemente de sua nação de origem. "O Estado não pode ferir essa garantia e deve fomentar os meios básicos para toda e qualquer pessoa possa completar seu ciclo de vida em ordem natural, sem dessemelhanças, desde o nascimento até a morte.” (Duarte, 2019). Ao se referir a necessidade de manter um nível mínimo de vida, isto é, manter uma vida digna, remete-se a outros direitos garantidos pela Constituição Federal, em seu art. 5º, parágrafo XXIII - à alimentação adequada, à moradia (art. 5º XXIII), art. 196 - ao vestuário, à saúde, art. 205 - à educação, art. 215 - à cultura, e art. 217 - ao lazer (Brasil, 1988). Neste âmbito, o direito à vida se cumpre valendo-se de um aparato estatal que seja capaz de ofertar amparo à pessoa que não tenha recursos necessários para seu sustento (Tavares, 2012). 
Não obstante, destaca-se um embate traçado pela literatura acerca do momento ao qual se considera que um ser humano está vivo, e do mesmo modo, o momento em que a existência humana cessa e com isso o dever do estado de manter e prover esta vida. Assim, há diversas teorias propostas para explicar esses fenômenos, e isso acaba gerando também empasses no âmbito jurídico.

De uma forma geral, o início desse direito se dá como uma questão biológica, no entanto, figuram diversas teorias: teoria da concepção; teoria da nidação; teoria da implementação do sistema nervoso; teoria dos sinais eletroencefálicos. A teoria da concepção, adotada pela Igreja Católica, é fortemente endossada no direito brasileiro, defende que a vida humana existe desde a concepção. A teoria da nidação determina a ocorrência da vida após a fixação do óvulo no útero. A teoria da implementação do sistema nervoso destaca a presença de vida após o surgimento de rudimentos do que será o sistema nervoso central. E existe ainda a teoria de que somente o nascimento no sentido da exteriorização do ser é que conceberia o direito à vida (Tavares, 2012).

Como a vida se constitui como o mais importante bem jurídico tutelado, há um tratamento distinto no que diz respeito ao direito penal. Além da prática de homicídio, a não tipicidade penal da tentativa de suicídio, há o enquadramento como crime do ato de instigar e auxiliar o suicida a praticá-lo. Para a justiça, há uma compreensão de que a vida possuí caráter indisponível, não sendo permitido que alguém desista de viver. "Essa ação, por esse entendimento, feriria o interesse público de preservar a vida, principalmente frente à realidade irreversível da morte.” (Duarte, 2019).

Assim, no contexto brasileiro, não há tolerância para a denominada "liberdade à própria morte". Não é possível impedir que alguém se desfaça de seu direito à vida, suicidando-se, e ao mesmo tempo, a morte não é um direito subjetivo do indivíduo, e dessa forma, não pode ser exigida. Portanto, não existe uma maneira válida de exigir, do Estado ou de outros, a morte como uma maneira atenuante dos sofrimentos. E em contrapartida, também não se pode admitir a cessação do prolongamento artificial da vida de alguém. Logo, a eutanásia é considerada uma forma de homicídio. Destaca-se assim, a prevalência do direito à vida, em detrimento da dignidade humana (Tavares, 2012).

Empreende-se que o Estado precisa defender a vida, de uma maneira que garanta a vida humana em todos os seus âmbitos, a partir da oferta de todos os meios necessários para a manutenção da dignidade de todos os sujeitos, e não somente se comprometa com a mera existência orgânica. A compreensão da vida deve incluir parâmetros transcendentes de juízos meramente biológicos e objetivos, considerando um aglomerado de elementos e condições subjetivas que visam o bem estar físico e psicológico dos indivíduos; além de incluir ponderações de acordo com o princípio da dignidade da pessoa humana. Neste sentido, concluindo que o direito à vida é um direito fundamental, este deve se adequar ao conceito atual de vida digna. Não obstante, uma das faces da dignidade humana é a liberdade que cada ser possui para conduzir a forma de sua própria existência com suas próprias escolhas, convicções e valores. Essa responsabilidade é capaz de manifestar a autonomia do sujeito e sua capacidade de autodeterminação, tendo repercussões individuais e coletivas. Nesse contexto, a autodeterminação, ou autonomia privada, está intimamente ligado à dignidade humana, pois dá as pessoas o poder de decisão sobre suas escolhas em vida, sem coação de outrem ou do Estado. "É ligado fundamentalmente também ao direito de liberdade. Traz a premissa que de que. com sua vontade, o indivíduo possa agir com autonomia.” (Duarte, 2019).

Assim, como uma coisa está vinculada a outra, não é possível pensar em uma e não em outra. Sobre a possibilidade de optar pela morte na terminalidade da vida, há uma discussão acerca de que vida o paciente vai viver apenas com a manutenção das funções vitais à custo de muita dor e sofrimento, sem perspectiva de melhora e retorno à vida normal. Dessa forma, entra um debate acerca de se viver dignamente e não apenas viver, o direito à uma morte digna e respeito à autonomia do paciente.

Muitas pessoas passam anos vivendo com doenças degenerativas e irreversíveis incuráveis, e requerem a antecipação do fim do curso do mal que os afligem para terem uma morte digna, enquanto outros não são capazes de manifestar sua vontade em decorrência, por exemplo, de uma situação de coma irreversível. O que se destaca aqui é que não há maneira de 
exercer uma vida digna, inexistindo sentido para a existência da pessoa. Assim, a vida deixa de ser um direito e torna-se o oposto, uma obrigação. Assim, é necessário falarmos acerca de uma morte digna (Duarte, 2019).

Vale ressaltar, portanto, que na Constituição Federal brasileira, a dignidade da pessoa humana aparece equivalente ao direito à vida, logo, uma não pode ser sobreposta à outra, assim, faz sentido pensar numa morte digna. Não obstante, a morte é um processo natural, fazendo parte da vida tão igualmente a qualquer outro ciclo da vida, e dessa forma, deve ser vivida de uma forma digna, e não sofrida, como o homem a transformou, a partir de inúmeras maneiras de se prolongar artificialmente a vida.

Em adição, dispõe-se que o efetivo reconhecimento das DAV's, nos permite inferir que o direito à vida não se opõe ao direito a uma morte digna, sendo que ambos estão ligados pelo fundamento constitucional da dignidade da pessoa humana. Complementa-se, ao tratar do direito à vida como um direito à vida digna e não somente ao fato de manter funções vitais, incorrendo-se a mesma lógica à medicina, que possui o dever de salvar a vida, não a qualquer custo. Posto isto, refere-se que o princípio da dignidade da pessoa humana associado com outros direitos, como a autonomia privada e o próprio direito à vida, é capaz de fundamentar e legitimar o direito de morrer dignamente nos contextos em que determinando sujeito, com estado clínico grave e irreversível, associado a um grave sofrimento físico, moral e psicológico, requer a antecipação de sua morte por meios menos nocivos (Cunha, 2019).

Assim, as DAV’s estão inseridas nesse cenário e possibilitam a efetividade destes direitos aos pacientes terminais, que na impossibilidade de cura de um agravo, podem recorrer a este recurso. Sua aplicação deve ser precedida de todos os esclarecimentos necessários, ao passo que só assim haverá realmente uma garantia dos direitos desse paciente.

\subsection{Diretivas antecipadas de vontade}

Com o passar dos tempos, inúmeros avanços permitiram ao ser humano um certo "controle da morte" nunca visto anteriormente. Portanto, o ser humano passou a ter novos recursos no combate à cessação da vida. Inúmeros métodos diagnósticos, terapêuticos e postergadores da vida passaram a fazer parte da ciência médica contemporânea. Contudo, geralmente, o emprego destes no cuidado ao paciente se dá acompanhado de dor e sofrimento, ocorrendo um prolongamento artificial da vida, uma obstinação terapêutica, comprometendo a dignidade do paciente, sendo que muitos evoluem para um estado considerado "vegetativo", que seria o coma. Em vista disso, há o desejo por parte de determinados pacientes, de um tratamento que considere suas reais vontades, as quais, na maioria das vezes, estão associadas à escolha de terapêuticas menos invasivas e dolorosas, ou até mesmo dizem respeito à uma morte digna, e a não aceitação de um prolongamento artificial da vida sem um melhor prognóstico. Nesse contexto, surgiu a discussão acerca das DAV's, a partir também da visualização de uma necessidade de respeito à autonomia do paciente.

O conceito de DAV’s já foi elucidado na literatura por distintos autores, estando ligados sempre a um tipo de registro das informações dadas por um paciente acerca de suas preferências em relação à terapia empregada. Não obstante, estas constituem-se como um importante mecanismo jurídico, haja visto que os pacientes que requerem sua aplicação são aqueles que se encontram em uma situação crítica de saúde, estando debilitados e possivelmente necessitando de cuidados de maior complexidade, que envolvem procedimentos invasivos.

Assim, as DAV's podem ser definidas como documentos através dos quais o paciente, desde que esteja lúcido e capaz, elucida recomendações para guiar seus cuidados, procedimentos e tratamentos médicos, quando existem hipóteses de que este mais tarde não vá dispor de consciência e autonomia para defender sua vontade e fazê-la prevalecer; ou ainda mediante os quais constitui um procurador a fim de que o mesmo possa sustentar suas vontades em nome dele (Stersi, 2020). Penalva (2009) dispõem que as DAV’s se constituem em gênero, a partir do qual o testamento vital e o mandato duradouro são 
espécies. Isto é, são modalidades de DAV’s, sendo que na primeira, o paciente, por si mesmo, manifesta as suas vontades e já na segunda, um representante eleito pelo paciente é quem toma as decisões oportunas.

Antes de analisar esse conceito com maior profundidade, vale ressaltar o contexto histórico de seu surgimento. É possível observar que a relação entre médicos e pacientes é permeada por algumas questões emblemáticas, como por exemplo, o poder que essa figura representada no imaginário das pessoas. De certo modo, durante muito tempo, os médicos eram tidos como detentores do conhecimento, enquanto os enfermos eram apenas expectadores de seu sofrimento e não podiam decidir sobre seu tratamento, fato que possivelmente ainda hoje ocorre em muitos cenários.

Contudo, a partir de questionamentos que foram sendo feitos, modificações nas políticas públicas e nas legislações vigentes, o paciente foi deixando de ser simplesmente "paciente" e ganhando maior poder de fala junto aos profissionais de saúde. Ao considerar isso, visualiza-se que as DAV’s emergiram a partir deste novo ideário, visualizando-se a necessidade de preservar o paciente e seus direitos.

O histórico das DAV's remonta a década de 1970, a lei federal estadunidense Patient Self-Determination (PSDA), considerada a precursora na regulamentação das DAV's, o objetivo desta lei consistiu na proteção da autodeterminação da vontade dos pacientes nas decisões que envolvessem os cuidados de sua saúde. Destaca-se que ocorreu assim um grande avanço para a comunicação na relação entre médico e paciente, mudando um pouco de uma visão paternalista existente, em que o médico era quem tinha o poder das decisões sobre a saúde de determinado paciente, sendo existente uma submissão da vontade deste último (Dadalto, 2013).

Desde a sua promulgação, foram traçadas dissimilitudes entre as DAV's, o testamento vital e o mandato duradouro. No entanto, dispõe-se que até hoje há uma confusão acerca dos institutos, sendo utilizados como sinônimos muitas vezes (Stersi, 2020). Incumbe destacar que ambos são instrumentos que tem como objetivo fazer prevalecer a vontade do indivíduo para que, em caso de incapacidade (temporária ou permanente) daquele, seus desejos sobre seu próprio tratamento e os cuidados médicos se façam presentes (Avila \& Lazaretti, 2020).

A formalização das DAV's no contexto norte-americano se dá a partir de um documento em que o enfermo descreve os tratamentos pelos quais não deseja ser submetido quando estiver em estado de coma ou em outros casos em que é impossibilitado de expressar sua vontade. A expressão da vontade nesse instrumento, é sobreposta à vontade dos profissionais da saúde, familiares, amigos, tutores ou curadores, sendo que este documento requer assinaturas de duas testemunhas. Ademais, este documento precisa ser entregue ao médico pessoal, cônjuge, advogado ou ao confidente do paciente, devendo ser referendado pelo Comitê do hospital em que o paciente estiver sendo assistindo. Contudo, este documento pode ser revogado a qualquer tempo até que o paciente esteja inconsciente (Dadalto, 2018).

Godinho (2012) corrobora descrevendo as DAV's como o gênero de manifestação da autonomia de vontade a respeito de tratamentos e procedimentos médico-cirúrgicos que é desejado ou não sua aplicação na pessoa natural, isto é, mediante a este instrumento que o enfermo poderá exercer sua liberdade e tomada de decisão frente aos tratamentos, procedimentos e a assistência ofertada, os quais são aplicados ao seu próprio corpo. Portanto, estão dispostas informações fundamentais no que se refere ao desejo ou não do paciente a se submeter a tratamentos inofensivos ou ainda até cirurgias invasivas e arriscadas.

De acordo com Sá (2012), as DAV’s podem ser vistas como uma projeção da autonomia privada para o futuro, e assim, é considerada um negócio jurídico que tem como capacidade a antecipação da vontade individual, uma vez que o que está descrito deverá ser implementado em um momento posterior. Inicialmente, seu surgimento se deu com o intuito de limitar a intervenção médica não curativa, isto é, a obstinação terapêutica, se aplicando principalmente em casos de doenças terminais ou inconsciência irreversível. Todavia, na atualidade, é empregada também no caso de o paciente recusar determinadas opções terapêuticas e optar por uma assistência a qual ele prefira, aplicando-se no futuro, principalmente quando o doente estiver inconsciente. 
Em geral, as DAV’s são uma forma de valorizar a autonomia pessoal, objetivando o respeito às escolhas esclarecidas das pessoas tendo por objeto o próprio corpo. Assim, consiste em um possível impedimento à obstinação terapêutica, uma vez que a pessoa natural expressará sua escolha, no que diz respeito a determinado tratamento médico que valorize sua qualidade de vida, isto é, "que consista no enaltecimento da vida digna e, também, da morte digna, menos dolorosa e sofrida." (Angeluci \& Bongardi, 2020).

Através desse instrumento é oportunizado ao paciente que este se autodetermine diante da vontade dos médicos e familiares no contexto da assistência à saúde. A preservação da autonomia, quando falamos de tratamentos médicos, deve incluir como premissa a possibilidade de o sujeito recusar determinado procedimento que poderia ser aplicado ao mesmo. No contexto brasileiro, isso se respalda na Constituição Federal, em especifico, no direito à liberdade, "garantindo que a vontade do paciente se sobreponha à opção terapêutica escolhida pelo profissional da saúde, desde que seja uma decisão consciente e após as informações devidas.” (Dantas, 2019).

Assim, nada mais seriam as DAV’s, senão, uma maneira de proteger juridicamente a possibilidade do paciente de escolher seu tratamento diante das possibilidades ofertadas pela medicina. O paciente se posiciona frente ao médico, seu tratamento e sua família, ancorando-se no direito para fazer valer sua vontade. Trata-se de um recurso de grande valia, tendo em vista que muitas vezes a vontade da pessoa enferma não é cumprida pelo médico que o assiste, pelos membros da família e/ou outros, logo, esse respaldo jurídico é uma maneira de garantir que isso não ocorra.

Cabe dispor que não são raros os casos em que as alternativas terapêuticas dispostas aos pacientes podem trazer maior sofrimento, em decorrência do mal-estar e efeitos colaterais associados à terapêutica. Em frente a isso, as DAV's podem proporcionar à pessoa enferma a oportunidade de optar por opções terapêuticas menos invasivas, assim sendo, a mesma poderá, por exemplo, decidir por cuidados paliativos, preservando sua personalidade no momento de finitude da vida humana (Teixeira \& Sá, 2018), e ainda sua qualidade de vida em detrimento do sofrimento gerado por procedimentos que o paciente não quer se sujeitar.

A capacidade de se autogovernar diz respeito à autonomia, a manifestação da subjetividade do ser humano, no ato de elaborar leis que conduzem sua própria vida e coexistem com as normas criadas pelo Estado (Teixeira, 2018). Dessa maneira, a instauração das DAV's tratam-se de uma forma de manifestação da autonomia existencial, estando associadas à capacidade de autorregulação do indivíduo, instando na possibilidade de decidir sobre procedimentos médicos que se deseja ou não que sejam aplicados a si mesmo (seu corpo) "e, sendo uma decisão consciente e informada, de índole eminentemente individual, deve ser respeitada por todos e observada pelos profissionais da saúde vida.” (Angeluci \& Bongardi, 2020).

Assim, evidencia-se que a aplicação das DAV’s tem a contribuir em muito para o seguimento de uma assistência à saúde mais imparcial, sendo um instrumento que dá um poder, que deveria ser de posse do paciente desde o início dos tempos, o de tomada de decisão sobre seu tratamento e cuidados de saúde, o que anteriormente pertencia ao médico e equipe de saúde. Outrossim se refere à relação das DAV’s com a autonomia, que está explícita e não há como questionar, tornando mais importante ainda a implementação das DAV's no contexto da assistência à saúde.

Como mencionado anteriormente, ainda existe literatura oculta sobre as DAV's e suas formas, modalidades ou ainda espécies. Considerando isso, faz-se necessário distinguir de uma forma mais clara o testamento vital do mandato duradouro, consideradas espécies do gênero DAV’s. Este subítulo será dedicado ao testamento vital enquanto o seguinte ao mandato duradouro.

O testamento vital tem seu surgimento pela primeira vez pela Euthanasia Society of America, recebendo a nomenclatura living will. Em síntese, seria o "documento elaborado pelo paciente com o intuito de estabelecer os tratamentos médicos que pretende ou não se submeter, nas hipóteses de doenças terminais ou danos irreversíveis, quando não gozar de autonomia e consciência para fazer predominar os seus desejos." (Stersi, 2020). 
Assim sendo, o testamento vital pode ser definido como a expressão do mais alto grau de autonomia. "Manifesta-se de forma escrita, sem maiores requisitos formais, que de maneira clara, lúcida e transparente, eivada de vícios do consentimento, seja porta-voz das vontades do sujeito no tocante aos tratamentos médicos.” (Salvador, 2017). O Testamento Vital pode ser caracterizado como "um instrumento ético/jurídico que permite reforçar a autonomia da pessoa, podendo ser complementado com a nomeação de um procurador de cuidados de saúde ou mesmo com um conjunto de instruções médicas tomadas previamente com o consentimento do doente.” (Nunes, 2012).

Após o testamento vital, cabe descrever o mandato duradouro, uma segunda espécie das DAV’s. Enquanto a primeira se refere aos escritos de uma pessoa acerca de sua vontade com relação à sua terapêutica, esta segunda modalidade está ligada à nomeação de alguém que terá como objetivo "fazer cumprir a vontade do interessado", ou seja, um paciente em terminalidade de vida deixa alguém responsável por determinar decisões futuras acerca de seu tratamento, conforme a assistência vai sendo prestada.

O mandato duradouro sobreveio após o testamento vital, no ano de 1983, por meio de uma lei do estado da Califórnia e mais tarde pela lei federal norte-americana Patient Self-Determination, já referida anteriormente (Stersi, 2020). Para Luciana Dadalto (2018), o mandato duradouro: “[...] é um documento no qual o paciente nomeia um ou mais procuradores que deverão ser consultados pelos médicos em caso de incapacidade do paciente. O procurador de saúde decidirá tendo como base a vontade do paciente."

O instituto do mandato duradouro pressupõe a constituição de um mandatário, aí designado "procurador de cuidados de saúde", que recebe poderes expressos para, ao agir em nome do paciente e segundo instruções por ele transmitidas, decidir acerca dos tratamentos e cuidados com a saúde o próprio representado admite ou rejeita para si. O referido procurador, portanto, atuará como um interlocutor entre o paciente, cujas instruções deverá fielmente seguir, e a equipe médica (Godinho, 2012).

Independentemente de qual instrumento a ser utilizado, o resultado esperado dessa ação é o mesmo, a garantia de que a vontade do paciente seja cumprida, para que tratamentos indesejáveis, o prolongamento artificial da vida, dentre outros fatores que fazem com que o paciente sofra, sejam evitados. Desse modo, reforça-se que deve se ter meios legais suficientes para que a implementação das DAV’s seja efetivada nos mais diversos cenários.

Além disso, cabe destacar que como cada ser é único, em sua subjetividade, esta autodeterminação proporcionada pelas DAV's, vai proporcionar um tratamento mais autêntico, mais digno, e ao mesmo tempo fará parte do tratamento, pois essa oportunidade dada ao paciente de decidir acerca de seu tratamento ou de quem ele quer que decida sobre seu tratamento futuro, por si só, também é terapêutica. O indivíduo, ao tomar decisões, se sente útil, se sente capaz, se sente digno, e assim, este pode sentir que sua existência tem sentido, e que é o verdadeiro dono de si, exercitando sua capacidade de autonomia, podendo assim morrer dignamente, caso seja de sua vontade.

As DAV’s são demandas existentes para regulamentar a vontade de pacientes que desejam decidir sobre o tratamento, ou por vezes, até mesmo a interrupção do mesmo. Essa vontade abrange um amplo campo de possibilidades às quais a pessoa enferma pode querer recorrer para cessar a situação de sofrimento que muitas vezes se encontra, dentre as quais podem ser observadas o desejo pela eutanásia ou a ortotanásia. Por outro lado, quando não se cumpre a vontade do paciente e ele é submetido a um tratamento doloroso, a distanásia pode ocorrer.

Assim, faz-se necessário a distinção entre esses conceitos além de o entendimento acerca do que está disposto no ordenamento jurídico brasileiro acerca disso. Inicialmente, ressalta-se que estes não são permitidos na nossa Constituição Federal, que defende veementemente a vida, no entanto, sua discussão, pode se inserir, em determinados casos, no direito fundamental à dignidade da pessoa humana, e por consequência, inferindo-se a necessidade de um direito à morte digna. 
A palavra "eutanásia" vem do grego, sendo delimitada como uma "boa morte" ou "morte digna". No contexto médico, pode ocorrer de distintas maneiras, por meio da antecipação da morte do paciente. Destaca-se que para o ordenamento jurídico brasileiro constitui-se em um crime de homicídio, pois a pessoa não irá morrerá em decorrência da doença e sim de uma prática realizada por terceiro, que efetivamente findará a vida do paciente, mesmo que isso represente um desejo do interessado (Nascimento et al., 2021).

De um ponto de vista parcial, considerando a necessidade de preservar o direito à autonomia do indivíduo, esta atitude encontraria um aval. Do contrário, ao evidenciar o direito fundamental à vida em primeiro lugar, este ato seria reprovado veementemente. Logo, não se pode dispor de uma resposta concreta, o que torna mais complexo ainda a discussão desse tema. No entanto, temos fatos a serem seguidos, que são as disposições já impostas juridicamente, que hora são questionáveis, hora não, neste caso, parece haver predominância da limitação da autonomia do paciente nesse sentido.

Defende-se na literatura a ortotanásia como a "eutanásia" em sua forma mais correta, uma vez que determinam que não se trata de uma antecipação da morte do indivíduo, e sim a ocorrência do óbito na hora mais correta, mediante a participação de um segundo sujeito de forma ativa ou passiva visando o alívio do sofrimento da pessoa (Nascimento et al., 2021). Na ortotanásia, há supressão de métodos clínicos extraordinários de manutenção da vida. Assim, as pessoas em estado de terminalidade de vida que manifestarem interesse (livre e esclarecido) em encerrar as terapias podem decidir pela ortotanásia. Isso não significa encerramento da terapia paliativa, que segue com intuito de diminuir a dor e o sofrimento dos momentos finais da vida (Salvador, 2017).

Entretanto, não se pode confundir uma com outra, apesar de que ambas têm como propósito não prolongar o sofrimento humano do sujeito na terminalidade da vida. Ao contrário da eutanásia, não se considera que há um ato criminoso na ortotanásia, uma vez que se deixa seguir o curso esperado da doença sem intervenção por parte dos profissionais da saúde. Em vista disso, a ortotanásia encontra mais aceitação, inclusive entre o meio jurídico, sendo permitida sua realização pela equipe médica se for de vontade do paciente esclarecido, estando em conformidade com o código de ética dos profissionais da medicina.

Outro termo relacionado que aparece bastante é a distanásia, sendo o oposto da eutanásia, consistindo na prorrogação da morte através da utilização de todos os métodos possíveis para evitar o óbito, incidindo numa morte lenta e sofrida. Portanto, não é oportunizado uma morte na hora correta, sendo que essa prática pode se configurar como uma lesão corporal ao paciente ou constrangimento ilegal (Nascimento et al., 2021).

A distanásia aparece em contraposição ao processo de morrer com dignidade, e aparece como uma preocupação para a Bioética contemporânea. A expressão tem origem na Grécia antiga, sendo que dis significa "afastamento" e thanatos, "morte". Desse modo, tem como definição, em sua etimologia, "afastamento da morte". Logo, se caracteriza pela postergação sofrida da morte, prolongando-se o processo de morrer e não a vida propriamente dita, em que a pessoa já se encontra em fase terminal de uma doença e que nenhum procedimento será capaz culminar na cura (Cabral et al., 2018).

A distanásia também é conhecida como obstinação terapêutica, e sua ocorrência deve se a diversos avanços tecno científicos na área da saúde humana com o intuito de controlar e prolongar, excessiva e quantitativamente o processo de morte, que na realidade já se iniciara na terminalidade da vida, a partir da constatação da irreversibilidade do quadro clínico, submetendo o paciente a um sofrimento extremo por uma exaustiva utilização de procedimentos e medicamentos desnecessários. Através da distanásia, verifica-se o expressivo poder que a Medicina tem sobre a vida dos sujeitos, ao tentar medicalizar o corpo humano o máximo possível, impondo tratamentos fúteis que em nada contribuirão para a cura, melhora e/ou reversão do quadro do paciente (Cabral et al., 2018).

Nesse sentido, deve ser destacado que a Bioética contemporânea vem se preocupando em estabelecer o limite a partir do qual um tratamento se torna fútil, desnecessário ou mesmo lesivo à dignidade do paciente. Essa obstinação terapêutica 
ocorre quando uma pessoa é levada ao sofrimento extremo, mediante submissão ao uso excessivo de medicamentos e procedimentos, trazendo risco a sua dignidade, ou mesmo chegando a ocorrer em morte indigna. Dessa maneira, avalia-se que a distanásia está longe de promover a morte digna, configurando desrespeito ao indivíduo, instrumentalizando-a, quer pela vontade dos familiares, quer pela conduta obstinada da equipe médica que entende a morte como um fracasso da Medicina (Cabral et al., 2018).

Desse modo, ressalta-se a relevância da ortotanásia diante da distanásia, pois possibilitará ao sujeito que encare a terminalidade da vida com mais dignidade e menos penar (Salvador, 2017). Em que se pese a relação desses termos com as DAV’s, observa-se o que Penalva (2009) descreve acerca da declaração prévia de vontade do paciente terminal não ser um instrumento para realização da prática de eutanásia, e sim, para garantir a ortotanásia. Nesse sentido, a distanásia é algo prejudicial e não aceita pelo ordenamento jurídico brasileiro, devendo ser evitada no âmbito da assistência à saúde.

Elucida-se três conceitos importantes, os quais devem ser refletidos à luz dos direitos humanos fundamentais, garantidos na Constituição Federal, devendo ser garantidos a todo ser humano em sua principalidade. A eutanásia apesar de delimitada como uma "boa morte” não encontra respaldo na legislação atual brasileira, a ortotanásia encontra amparo em alguns aspectos, no entanto ainda sua discussão é limitada e a distanásia aparece como uma obstinação terapêutica, que prolonga o sofrimento da pessoa humana.

\subsection{Diretivas antecipadas de vontade e ordenamento jurídico brasileiro: discussão acerca da necessidade de uma lei específica regulamentadora}

Como visto anteriormente, as DAV's não estão respaldadas em uma lei específica no ordenamento jurídico brasileiro, todavia, estas podem ser embasadas em outros dispositivos legais existentes no contexto nacional. A Constituição Federal, conforme já apontado, trata-se do equipamento maior, em termos de garantir a instituição das DAV's por meio da primazia dos princípios constitucionais. Conforme discutido no primeiro subtítulo, os princípios que guardam relação direita com as DAV’s, são a autonomia privada, a dignidade da pessoa humana e o direito à vida, que, ao contrário do que é pensado por muitos, não é paradoxal ao ato da pessoa decidir, na terminalidade da vida, suspender os tratamentos e requerer a ortotanásia.

As resoluções do Conselho Federal de Medicina (resolução no 1.805/2006 e resolução 1.995/2012) servem para elucidar alguns aspectos importantes específicos, contudo, são mais uma espécie de guia para os profissionais médicos do que instrumento jurídico propriamente dito.

A Resolução 1.805/2006 basicamente permite ao médico a limitação ou suspenção de tratamentos prolongadores da vida do enfermo na fase terminal com patologias graves e incuráveis, desde que seja de sua vontade ou de seu representante legal (Dadalto, 2018). Vale destacar que nesse documento o Conselho Federal de Medicina se ampara no princípio constitucional da dignidade da pessoa humana e o inciso inc. III do art. $5^{\circ}$ da Constituição Federal que estabelece que "ninguém será submetido a tortura nem a tratamento desumano ou degradante".

Isto posto, ainda se sobressaiu outra problemática. Apesar de haver possibilidade da ortotanásia, há casos, em que, pessoas na terminalidade da vida, que seriam elegíveis para sua ocorrência, muitas vezes, se encontram em estado de inconsciência, não podendo manifestar sua vontade acerca de quais tratamentos gostariam ou não de receber. Diante desse cenário, houve a edição de uma nova resolução pelo Conselho Federal de Medicina.

Trata-se da Resolução n ${ }^{\circ} 1.995$, de 31 de agosto de 2012, que versa sobre as diretivas antecipadas de vontade, as quais são delimitadas pelo artigo $1^{\circ}$ como: [...] o conjunto de desejos, prévia e expressamente manifestados pelo paciente, sobre cuidados e tratamentos que quer, ou não, receber no momento em que estiver incapacitado de expressar, livre e autonomamente, sua vontade (Conselho Federal de Medicina, 2012). 
A referida ainda disserta que o médico deve levar em consideração as diretivas caso o paciente esteja impossibilitado de se expressar ou ainda levar em consideração o que é expresso por um representante legal, quando o paciente nomear este, desde que, as escolhas não firam os preceitos éticos da Medicina. Importa ainda destacar que as DAV’s devem prevalecer sob qualquer outra decisão não médica, ou seja, disposta por familiares ou outros.

Nesse sentido, as DAV's se tornam uma maneira de praticar a ortotanásia, estando ambas resguardadas em resoluções do Conselho Federal de Medicina. Essas resoluções têm em comum um movimento em torno do aumento da autonomia do indivíduo, no que se refere à escolha de tratamentos médicos e até mesmo de sua morte digna. O paciente estabelece suas escolhas ou deixa a cargo de um responsável legal, ao passo que, a Medicina reconhece esse direito que lhe é dado.

A partir destas resoluções, é oportunizado à pessoa na terminalidade de vida, que ela conduza seus últimos momentos de sua existência, dando mais sentido, inclusive, à sua vida e sua morte, evitando o sofrimento desnecessário e que decisões que são de sua incumbência fiquem para outrem. No entanto, insta observar, quanto aos efeitos legais, que as mesmas não possuem caráter legislador, isto é, não possuem efeito de lei ou de norma jurídica, e dessa forma, servem apenas para orientar o trabalho médico.

Os projetos de leis, dizem respeito a criação de novas normas jurídicas para sanar lacunas existentes no ordenamento jurídico de uma nação. No âmbito nacional, há o conhecimento de quatro projetos de lei relacionados às DAV's: o Projeto de Lei $\mathrm{n}^{\circ}$ 524/2009, o Projeto de Lei $\mathrm{n}^{\circ} 5.559 / 2016$, e mais recentemente, o Projeto de Lei $\mathrm{n}^{\circ}$ 149/2018 e o Projeto de Lei ${ }^{\circ}$ $267 / 2018$.

O Projeto de Lei $n^{\circ} 524 / 2009$, tratava sobre os direitos do paciente em fase terminal de alguma doença "no que diz respeito à tomada de decisões sobre a instituição, a limitação ou a suspensão de procedimentos terapêuticos, paliativos e mitigadores do sofrimento." Destacava-se que a pessoa na terminalidade de sua vida "[...] tem direito, sem prejuízo de outros procedimentos terapêuticos que se mostrarem cabíveis, a cuidados paliativos e mitigadores do sofrimento, proporcionais e adequados à sua situação." (Brasil, 2009).

Logo, este projeto de lei tinha como intuito, em seu surgimento, firmar juridicamente o que o Conselho Federal de Medicina, outrora, tinha postulado para os médicos seguirem. No entanto, destaca-se que houve um arquivamento deste projeto ao final da legislatura daquela época. Assim, não se obteve avanços nas discussões a respeito das DAV’s, até que em 2016, um novo projeto foi proposto.

O projeto de lei n ${ }^{\circ} 5.559 / 2016$, ainda em tramitação na Câmara dos Deputados, é de autoria do deputado Pepe Vargas (PT-RS). Segundo o projeto, o paciente poderá dispor do direito de indicar livremente um representante em qualquer momento de seus cuidados em saúde, por meio de registro em seu prontuário, menos nos casos em que o médico entender que a presença do acompanhante possa acarretar prejuízo à saúde ou à segurança do internado (Brasil, 2016).

Trata, portanto, dos direitos dos pacientes, ressaltando em seu artigo 20, o direito de os pacientes terem suas DAVs respeitadas, tanto pelos profissionais da saúde, como por seus familiares. Entretanto, não dispõe sobre a formalização deste documento, entre outras questões procedimentais, embora represente um avanço legislativo por introduzir as DAV's como uma questão existencial e personalíssima do paciente (Melo, 2018).

Portanto, mesmo se aprovado este projeto, haverá ainda uma inexistência de legislação que, de fato, regulamente as DAV's no Brasil. Este fato pode ocasionar insegurança jurídica, ao passo que não são delimitadas normas específicas para sua implementação, ficando ao encargo de cada jurista a interpretação. Refere-se que, um novo projeto, apresentado em 2018, vem ao encontro desta perspectiva de disciplinar as DAV's.

Trata-se do projeto de lei $\mathrm{n}^{\circ}$ 149/2018, que dispõe sobre as diretivas antecipadas de vontade e tratamentos de saúde. Visa o estabelecimento da possibilidade de que toda pessoa maior e capaz declare, de modo antecipado, quais tratamentos quer 
ou não se submeter futuramente, nos casos em que se encontre na terminalidade de vida ou acometido por uma doença grave ou incurável (Brasil, 2018). Este projeto encontra-se em tramitação, ainda aguardando designação de relator.

Diferentemente de projetos anteriores, este visa disciplinar as DAV’s, visando amparar juridicamente as ações em seu entorno. O projeto traz ainda a incumbência dos profissionais, e as situações em que podem se recusar a fazer cumprir as DAV's dos pacientes. Observa ainda que o paciente pode, em qualquer momento, modificar ou revogar suas diretivas, bem como ainda nomear um representante legal para decidir por ele. Com o intuito de esclarecer os pacientes sobre as diretivas, os ambientes públicos e privados de assistência à saúde devem dispor de pessoal capacitado para esta atividade.

Um outro projeto também foi elaborado em 2018, pelo Senador Paulo Rocha (PT/PA), o projeto de lei $n^{\circ} 267 / 2018$, trazendo em sua ementa o assunto das DAV’s acerca de cuidados médicos a serem submetidos os pacientes nas situações especificadas. Ressalta-se que este projeto teve sua tramitação encerrada devido pedido de retirada pelo autor do projeto, que justificou dispondo sobre a existência de outro projeto similar em tramitação, sendo o projeto apresentado anteriormente (projeto de lei no 149/2018). Desse modo, observa-se um percurso longo e que ainda não teve esgotamento, no que se refere a garantia legal do direito de o paciente exercer sua autonomia mediante as DAV's, que ainda não estão regulamentadas por norma jurídica.

No entanto, um projeto apresentado no ano de 2016, está em fase de tramitação, passando por diversas autoridades, enquanto outro, que fatidicamente visa disciplinar as DAV’s, ainda aguarda designação de relator. Assim, resta nos aguardar o que ocorrerá a seguir, todavia, destaca-se, de antemão, um avanço no que se refere a discussão acerca das DAV’s no país, considerando um passado não tão distante.

No que se refere ao arcabouço jurídico que ampara as DAV’s, encontramos além da Constituição Federal, outro instrumento jurídico pode auxiliar no assunto das DAV’s, o Código Civil brasileiro. O Código se relaciona com as DAV’s ao dispor vedações acerca de uma submissão compulsória dos pacientes a tratamentos quando há risco de morte, sendo considerado algo que não se pode renunciar.

Assim, avalia-se uma busca pela preservação da autonomia e dignidade inseridas intrinsecamente e indiretamente no código, ao passo que o mesmo não pode ser impedido de deliberar acerca de seu tratamento. As DAV’s vão de encontro a isso, servindo também para evitar também que os médicos e familiares decidam pelo paciente. No entanto volta-se a problemática das DAV's não estarem disciplinadas, sendo o Código Civil um instrumento usado em caráter complementar apenas para sustentar a implementação destas.

É possível fazer ainda uma relação do tema com o Código Penal Brasileiro. Esse instrumento também é vital para a organização da vida em sociedade, mantendo os indivíduos no cumprimento das leis. No código penal é tipificado como crime o constrangimento de alguém usando de violência ou ameaça grave ou mesmo a redução da capacidade do outro de resistência a não fazer o que a lei permite ou fazer o que ela não manda (Brasil, 1940).

Nesse contexto, o Código Penal também tem um caráter complementar na defesa das DAV’s, mas atribui importante valor. Considera-se que quando não se faz cumprir a vontade do paciente, este é submetido a um constrangimento ou ainda é submetido a outros danos. Esta conduta é condenada pelo Código Penal e merece ser observada no contexto da assistência à saúde dos pacientes em terminalidade da vida.

Como ainda não há lei específica que trate das DAV’s ainda se encontra em voga a discussão acerca da necessidade ou não de uma. Projetos de leis estão em tramitação, visando regulamentar do ponto de vista jurídico a implementação das DAV’s. Há argumentos de que o ordenamento jurídico brasileiro dá conta de efetivar as DAV’s sem lei específica, por outro lado, ressalta-se a falta de disciplinar as DAV`s, deixando margem para distintas interpretações em torno da temática.

Conforme aponta Angeluci (2019), a ausência de legislação vigente expressa sobre as DAV's no ordenamento jurídico brasileiro não se configura como impedimento para a validade e eficácia de disposições com tais conteúdos, sendo que 
se insere no campo da autonomia privada de vontade e não há nenhum impedimento legal quanto às questões relacionadas ao fim da vida de um indivíduo, sem desejo de antecipação da morte, mas apenas regulando, por declaração de vontade os procedimentos e tratamentos médico-cirúrgicos que se permite submeter.

Apesar de não se constituir impedimento à implementação das DAV's, Angeluci e Bongardi (2020) afirmam que essa ausência normativa conduz a pelo menos dois problemas: i) impede o acesso universal e conhecimento sobre a temática e, por conseguinte, sua difusão para o maior número possível de pessoas e ii) permite uma certa insegurança jurídica sobre o assunto, uma vez que a ausência regulamentar torna as pessoas reféns de interpretações variáveis quanto à validade e eficácia desses instrumentos.

Stersi (2020) complementa referindo a existência de uma grande dificuldade por parte dos juristas brasileiros ao se deparar com situações em que a vida de um indivíduo é colocada em xeque, ainda que isso decorra da própria vontade do mesmo. Refere ainda que apesar de estar presente nas resoluções do Conselho Federal de Medicina e em projetos de leis elaborados, as discussões sobre as DAV's ainda não se desenvolveram significativamente, prejudicando que estas sejam reconhecidas juridicamente. Disserta-se assim, que mesmo com avanços em relação aos cuidados paliativos no fim da vida e que a legitimidade das DAV’s no Brasil seja reconhecida, as normas, princípios constitucionais e resoluções que legitimam sua implementação, não esclarecem as controvérsias existentes, implicando em dificuldades para sua aplicação, o que justifica a necessidade de uma normativa específica que apresente delineamentos acerca de suas particularidades e da exata extensão de sua aplicabilidade (Stersi, 2020).

Portanto, pondera-se que o advento de uma lei tratando das DAV's, traria segurança jurídica e possibilitaria sua aplicação de forma mais adequada. A partir desta, haveria maior conhecimento do tema, e os profissionais de saúde poderiam se respaldar nos escritos da mesma. Assim, obteríamos mais ganhos do que perdas, com a aprovação de uma lei específica regulamentadora, tanto no contexto jurídico como social.

\section{Considerações Finais}

O objetivo deste trabalho foi analisar aspectos do ordenamento jurídico brasileiro relacionados às diretivas antecipadas de vontade e discutir acerca da necessidade de uma lei específica regulamentadora. No caminho para responder ao objetivo proposto, apresentamos nos resultados e discussão, três subtítulos que aprofundaram a temática mediante o uso de referências renomadas e atuais sobre o assunto.

No primeiro subtítulo, foram abordados os princípios constitucionais que são utilizados em casos concretos que envolvem a terminalidade de vida, e que embasam o trabalho em torno das DAV's. Discutiu-se a autonomia privada, a dignidade da pessoa humana, bem como o direito à vida e autonomia durante o processo da morte digna. No segundo subtítulo, explorou-se a especificidade das diretivas com maiores detalhes, os conceitos e a sua historicidade foram detalhados. Foi disposto acerca de duas modalidades de diretivas: o testamento vital e o mandato duradouro. Distinguiu-se ainda a eutanásia, distanásia e ortotanásia, ressaltando que as DAV’s devem permitir a ortotanásia em detrimento da distanásia e não favorecer a eutanásia.

No terceiro subtítulo, foram identificados e analisados aspectos do ordenamento jurídico brasileiro relacionados as diretivas, destacando-se as resoluções do Conselho Federal de Medicina, que não constituem normas jurídicas, os projetos de lei que foram arquivados e que se encontram em tramitação, e ainda, trechos da Constituição da República Federativa do Brasil, Código Civil e Código Penal que se relacionam com o assunto em pauta. Com base em outros autores e nas percepções dos autores do presente manuscrito, defendeu-se a necessidade de criação de uma lei específica regulamentadora para disciplinar as DAV's.

Evidenciou-se, ao longo do trabalho, a necessidade de algumas considerações a serem realizadas para o avanço do 
conhecimento acerca da temática. De início, ressalta-se o caráter complexo da terminalidade da vida, que abrange múltiplos aspectos e concepções acerca da morte e do morrer. A medicina e o direito ainda não findaram as discussões e disposições, sendo que muitas delas envolvem dilemas e empasses contundentes. Por muito tempo, o desejo dos pacientes em determinar suas vontades no fim da vida, ficaram à mercê dos profissionais da saúde, no que se refere às decisões acerca da assistência à saúde no final da vida. Por outro lado, isso era assegurado pelo ordenamento jurídico, gerando um forte paternalismo da medicina.

No entanto, com o passar dos anos, emergiram questionamentos acerca da autonomia e dignidade da pessoa humana, bem como da dignidade no processo de morrer e do direito não tão somente à vida, mas à vida digna no contexto da assistência à saúde. Ocorria e ainda ocorre que, muitas vezes, as pessoas em terminalidade da vida, com doenças graves e incuráveis, eram submetidas a procedimentos dolorosos e tinham um prolongamento artificial da vida, ferindo a autonomia e dignidade das mesmas. As pessoas eram impedidas de decidir sobre seu próprio corpo. Quando se observa a necessidade de garantir princípios e direitos fundamentais presentes na nossa Constituição, evidencia-se que estas não podem ser obrigadas a somente aceitar o que lhes é ofertado de assistência, não podendo morrer dignamente. Com o pensamento voltado para isso, defendeuse a necessidade de seguir as declarações feitas pelo paciente, culminando no surgimento das DAV`s.

Entretanto, sem amparo legal legitimado, ainda encontram dificuldades em sua aplicação. Somente as resoluções do Conselho Federal de Medicina, $\mathrm{n}^{\circ}$ 1.805/2006, e n 1.995/2012 dispõem especificamente sobre sua implementação, contudo não possuem efeito de norma jurídica. Assim, apesar de as DAV’s encontrarem aval na Constituição Federal, ainda há uma lacuna no ordenamento jurídico brasileiro para sua regulamentação efetiva, uma vez que inexiste algo que discipline e disponha aspectos específicos acerca destas.

Ao existir uma lei específica regulamentadora, o conhecimento das DAV's seria difundido, e os profissionais encontrariam muito mais confiança ao aplicá-las, além de que os pacientes estariam muito mais amparados ao lutar pelo direito de declaração acerca de suas vontades. Assim, avalia-se que a existência dessa lei é necessária e seria benéfica para um avanço no ordenamento jurídico brasileiro e na garantia dos direitos à população. Na ausência de lei específica, a Constituição sustenta a implementação das DAV's, a partir dos artigos $1^{\circ}$, inciso III e $5^{\circ}$, inciso II, que dizem respeito à dignidade e autonomia. E ainda, há no ordenamento jurídico, instrumentos complementares como o Código Civil, por meio das disposições do artigo 11 e 15 e o Código Penal em seu artigo 146, $\$ 3^{\circ}$, inciso I, dispondo, respectivamente, sobre crimes de homicídio e constrangimento ilegal.

Em conclusão, a medicina e o direito devem fazer valer as DAV's para garantir aos pacientes em terminalidade de vida uma morte digna, uma vez que a dignidade deve estar presente em todo o processo da vida, e a morte faz parte da vida, sendo um processo natural. O que não deve acontecer é o prolongamento artificial da mesma, contrariamente ao que o indivíduo deseja. Neste momento, todos os preceitos médicos que contrariem a vontade do sujeito devem ser deixados de lado, e a vontade, desde que haja o esclarecimento devido e não envolva o ferimento aos direitos de terceiros, deve ser considerada. Novos estudos necessitam ser realizados, tendo como objetivo explorar o fenômeno das DAV's na realidade brasileira, a partir de diferentes óticas, na esfera jurídica, médica e comunitária.

\section{Referências}

Alexy, R. (2015). Teoria dos Direitos Fundamentais. Malheiros.

Andrade, M. M. D. D. (2001). Introdução à metodologia do trabalho científico. (2a ed.), Atlas.

Angeluci, C. A. (2019). Considerações sobre o existir: as diretivas antecipadas de vontade e a morte digna. Revista Brasileira de Direito CivilRBDCivil, 21(03), 39. https://rbdcivil.ibdcivil.org.br/rbdc/article/view/464/307.

Angeluci, C. A., \& Bongardi, A. L. (2020). As diretivas antecipadas de vontade: uma perspectiva de inclusão. Meritum, Revista de Direito da Universidade FUMEC. http://revista.fumec.br/index.php/meritum/article/view/7774. 
Avila, G. N. de, \& Lazaretti, B. F. (2020). Das Diretivas Antecipadas de Vontade como instrumentos de proteção penal da personalidade no fim da vida. Revista Jurídica Cesumar-Mestrado, 20(3), 343-361. 10.17765/2176-9184.2020v20n3p343-361.

Barbosa, O. C. R. (2019). Diretivas antecipadas de vontade: a legitimação da autonomia e dignidade da pessoa humana no fim da vida. Trabalho de Conclusão de Curso, Universidade Presbiteriana Mackenzie, São Paulo, 2019. http://dspace.mackenzie.br/handle/10899/21118.

Barroso, L. R. (2014). A dignidade da pessoa humana no direito constitucional contemporâneo: a construção de um conceito jurídico à luz da jurisprudência mundial. Editora Fórum.

Borges, R. C. B. (2005). Disponibilidade dos Direitos de Personalidade e Autonomia Privada. Saraiva.

Brasil. (2002). Lei no 10.406, de 10 de janeiro de 2002. Institui o Código Civil. http://www. planalto. gov. br/ccivil_03/leis/2002 L, 10406, 1950-1969.

Brasil. (1940). Decreto-Lei, nº 2.848, de 7 de dezembro de 1940. http://www. planalto. gov. br/CCIVIL_03/Decreto-Lei/Del2848. htm.

Brasil. (1988). Constituição Federal de 1988. http://www. planalto. gov. br/ccivil_03/constituicao/constituicao.

Brasil. (2016). Projeto de Lei da Câmara dos Deputados no 5.559, de 2016. http://www.camara.gov.br/proposicoesWeb/fichadetrami tacao?idProposicao= 2087978 .

Brasil. (2018). Projeto de Lei do Senado n 149, de 2018. https://www25.senado.leg.br/web/atividade/materias/-/materia/132773.

Brasil. (2009). Projeto de Lei do Senado n 524, de 2009. https://www25.senado.leg.br/web/atividade/materias/-/materia/94323.

Cabral, H. L. T. B., Ribeiro, L. M. T. B., Boechat, I. T., Moreira, R. V., \& de Souza, C. H. M. A obstinação terapêutica e a morte indigna à luz da normativa do CFM. Temas em Saúde, 18(14), 84-100. https://temasemsaude.com/wp-content/uploads/2018/12/18405.pdf.

Carrapato, P., Correia, P., \& Garcia, B. (2017). Health determinants in Brasil: searching for health equity. Saúde Soc. São Paulo, 26(3), 676-689. https://scielosp.org/article/sausoc/2017.v26n3/676-689/pt/.

Carvalho, A. P. D. (2012). Direito de morrer de forma digna: autonomia da vontade. Orbis Rev Cient [Internet], 2(1), 15-29. https://www.cidp.pt/revistas/ridb/2013/02/2013_02_01009_01028.pdf.

Conselho Federal de Medicina. (2012). Resolução n. 1995/2012, de 9 de agosto de 2012. Diário Oficial da União. Brasília, Seção I, p. $269-70$.

Conselho Federal de Medicina. (2009). Resolução n.1.931/2009. Brasília: https://portal.cfm.org.br/images/stories/biblioteca/codigo\%20de\%20etica\%20medica.pdf.

Costa, N.C.G. (2019). O corpo ideal e a cultura fitness: configurações de um estilo de vida. Tese, Universidade Federal de Mato Grosso, Cuiabá, Mato Grosso, 2019. http://ri.ufmt.br/bitstream/1/1963/1/TESE_2019_Neuza\%20Cristina\%20Gomes\%20da\%20Costa.pdf.

Cunha, F. C. dos S. (2019). Diretivas antecipadas de vontade: a autonomia do paciente terminal. Trabalho de Conclusão de Curso, Centro Universitário do Estado do Pará, Belém, Pará, 2019. http://repositorio.cesupa.br:8080/jspui/handle/prefix/122.

Dadalto, L. (2018). Testamento Vital. (4a ed.), Foco.

Dadalto, L., Tupinambás, U., \& Greco, D. B. (2013). Diretivas antecipadas de vontade: um modelo brasileiro. Revista bioética, 21, 463-476. https://www.scielo.br/pdf/bioet/v21n3/a11v21n3.pdf.

Dantas, E. (2019). Respeitarei todas as suas opiniões que concordarem com as minhas. O Conselho Federal de Medicina e seu peculiar conceito de autonomia do paciente. Revista Jurídica Luso-Brasileira (RJLB),5 (6), 581-597. https://www.cidp.pt/revistas/rj1b/2019/6/2019_06_0581_0597.pdf.

Dayrell, L. de C. (2010). Ortotanásia - Aspectos Constitucionais e Penais como fundamentos do direito à morte digna. Trabalho de Conclusão de Curso, Escola Superior Dom Helder Câmara, Belo Horizonte, https://domtotal.com/direito/uploads/pdf/3bfdeee70f748d5c8d07699ab95574b9.pdf.

Duarte, H. F. (2021). O direito de morrer com dignidade: uma garantia constitucional implícita sob a perspectiva do princípio da dignidade da pessoa humana. Trabalho de Conclusão de Curso, Universidade Federal Rural do Semi-árido, Mossoró, Rio Grande do Norte, 2019. http://repositorio.ufersa.edu.br/handle/prefix/4534.

Ferreira, C.F. (2014). Guia de Estudos: Organização Mundial da Saúde (OMS). https://sinus.org.br/2014/wp-content/uploads/2013/11/OMS-Guia-Online.pdf.

Fuerst, L. A., \& de Paula, A. P. (2021). Diretivas antecipadas de vontade e o direito a uma morte (in) digna. Academia de Direito, 3, 22-47. http://www.periodicos.unc.br/index.php/acaddir/article/view/3094.

Godinho, A. M. (2012). Diretivas antecipadas de vontade: testamento vital, mandato duradouro e sua admissibilidade no ordenamento brasileiro. Revista do Instituto do Direito Brasileiro, São Paulo, 1(2), 945-978. https://www.academia.edu/.

Kant, I. (1986). Fundamentação da Metafísica dos Costumes. Edições 70.

Kant, I. (2009). Fundamentação da Metafísica dos Costumes. Discurso Editorial: Barcarolla,

Melo, V. R. de. (2018). Diretivas Antecipadas de Vontade: Construção de Bases Dogmáticas e Jurídicas. Revista de Direito, Viçosa, 10 (1), 251-279. https://periodicos.ufv.br/revistadir/article/view/1955. 
Research, Society and Development, v. 10, n. 16, e35101623323 2021

(CC BY 4.0) | ISSN 2525-3409 | DOI: http://dx.doi.org/10.33448/rsd-v10i16.23323

Nascimento, C. A. et al. (2021). Eutanásia. Jornal Eletrônico Faculdade Vianna Júnior, 13(1), 14-14. https://www.jornaleletronicofivj.com.br/jefvj/article/view/800.

Naves, B. T. D. O. (2014). O direito pela perspectiva da autonomia privada: relação jurídica, situações jurídicas e teoria do fato jurídico na segunda modernidade. Belo Horizonte: Arraes Editores.

Naves, B. T. D. O., \& Rezende, D. F. C. D. (2007). A autonomia privada do paciente em estado terminal. Direito Civil: Atualidades II Da Autonomia Privada nas Situações Jurídicas Patrimoniais e Existenciais. Belo Horizonte: Del Rey, 89-109.

Nunes, R. (2012). Testamento vital. Nascer e Crescer, 21, 250-255. http://hdl.handle.net/10400.16/1421.

Pargendler, M. S. (2004). A ressignificação do princípio da autonomia privada: o abandono do voluntarismo e a ascensão do valor de autodeterminação da pessoa. http://www.ufrgs.br/propesq/livro2/artigo_mariana.htm.

Penalva, L. D. (2009). Declaração prévia de vontade do paciente terminal. Dissertação, Universidade Católica de Minas Gerais, Belo Horizonte, Minas Gerais, 2009. http://www.biblioteca.pucminas.br/teses/Direito_PenalvaLD_1.pdf.

Reckziegel, J., \& Fabro, R. E. (2015). Autonomia da vontade e autonomia privada no sistema jurídico brasileiro. Revista de Direito Brasileira, 8(4), 161-177. https://indexlaw.org/index.php/rdb/article/view/2888/2690.

Sá, M. de F. F. de. (2012). Autonomia para morrer: eutanásia, suicídio assistido e diretivas antecipadas de vontade. Del Rey.

Salvador, G. M. de. (2017). As diretivas antecipadas de vontade: testamento vital. Trabalho de Conclusão de Curso, Universidade Federal do Paraná. http://hdl.handle.net/1884/55506.

Sarlet, I. W. (1998). A dignidade da pessoa humana. Revista de Direito Administrativo, 212, 84-94. https://www.maxwell.vrac.puc-rio.br/13488/13488_3.PDF.

Stersi, L. P. (2020). Diretivas antecipadas de vontade no Brasil: a necessidade da criação de uma lei específica. Trabalho de Conclusão de Curso, Pontifícia Universidade Católica, Goiânia, Goiás, 2020. https://repositorio.pucgoias.edu.br/jspui/handle/123456789/278.

Tavares, A. R. (2012). Curso de Direito Constitucional. (10a ed.), Saraiva.

Teixeira, A. C. B., \& de Sá, M. D. F. F. (2018). Cuidados paliativos: entre autonomia e solidariedade. Novos Estudos Jurídicos, $23(1)$, 240-258. https://siaiap32.univali.br/seer/index.php/nej/article/view/13037/7453. 